Original Article

\title{
An assessment of the urban water footprint and blue water scarcity: A case study for Van (Turkey)
}

\author{
Uma avaliação da pegada hídrica urbana e da escassez de água azul: um estudo de \\ caso para Van, Turquia
}

C. Yerli1 ${ }^{*}$ https://orcid.org/0000-0002-8601-8791, U. Sahin ${ }^{2}$ (D)

${ }^{1}$ Van Yuzuncu Yil University, Faculty of Agriculture, Department of Biosystem Engineering, Van, Turkey

${ }^{2}$ University of Ataturk, Faculty of Agriculture, Department of Agricultural Structures and Irrigation, Erzurum, Turkey

\begin{abstract}
Today, most of the world's population faces water scarcity, while global warming, urbanization, industrialization and population increases continue to increase the severity of the pressure on water resources. Management of water resources plays a key role in the sustainability of agricultural production. The water footprint (WF) is different in comparison to other water statistics because it takes direct and indirect water consumption into account, and helps in the management of water resources. Within this context, the WF of Van province, which is Turkey's most easterly located arid region, was calculated from 2004 to 2019. The study area covers lake Van, which is Turkey's largest lake, and the Van basin with an area of $23.334 \mathrm{~km}^{2}$ and a population of 1.136 .757 (2019). In the calculations, $\operatorname{crop}\left(\mathrm{WF}_{\text {crop }}\right)$, livestock $\left(\mathrm{WF}_{\text {livestock }}\right)$, and domestic and industrial water footprints $\left(\mathrm{WF}_{\text {domestictindustrial }}\right)$ were evaluated separately, and blue and green water footprints $\left(\mathrm{WF}_{\text {blue }}\right.$ and $\left.\mathrm{WF}_{\text {green }}\right)$ were analyzed in detail. According to the results, the average WF of Van province was found to be 8.73 billion $\mathrm{m}^{3}$ year $^{-1}$. Throughout the province, $87.6 \%$ of the $\mathrm{WF}$ is composed of $\mathrm{WF}_{\text {crop }}, 4.9 \%$ is $\mathrm{WF}_{\text {livestock }}$ and $7.5 \%$ is $\mathrm{WF}_{\text {domestictindustriall }}$. Of the $\mathrm{WF}_{\text {crop }}, 62.5 \%$ depends on $\mathrm{WF}_{\text {blue' }}$ i.e., freshwater. Most of the $\mathrm{WF}_{\text {livestock }}$ consisted of dairy cattle (49\%) and sheep (38\%). The average $\mathrm{WF}_{\text {domestictindustrial }}$ for 2004 to 2019 was 0.64 billion $\mathrm{m}^{3}$ year ${ }^{-1}$. The average per capita water footprint of Van province was found to be $889.9 \mathrm{~m}^{3}$ year $^{-1}$ capita $^{-1}$. In addition, the province is classified as severe water scarcity (257\%). This study is one of the first province-based calculations of WF in Turkey and is the first study to bring a different aspect to published literature by including residual soil moisture from the winter months. As a result of this study, the $\mathrm{WF}_{\text {blue }}$ of the $\mathrm{WF}_{\text {crop }}$ is above the worldwide average and should be reduced by changing the crop pattern or synchronizing the planting and harvest dates of the crops to a period that benefits from precipitation. In addition, this study is expected to contribute to new studies for calculating the provincial scale WF and will have positive effects on agricultural planning, water allocation and the sustainability of water resources.
\end{abstract}

Keywords: agricultural sustainability, blue water, green water, water footprint, water sustainability.

\begin{abstract}
Resumo
Hoje, a maior parte da população mundial enfrenta a escassez de água, enquanto o aquecimento global, a urbanização, a industrialização e o crescimento da população continuam a aumentar a gravidade da pressão sobre os recursos hídricos. A gestão dos recursos hídricos desempenha papel fundamental na sustentabilidade da produção agrícola. A pegada hídrica (WF) é diferente em comparação com outras estatísticas hídricas porque leva em consideração o consumo direto e indireto de água e auxilia na gestão dos recursos hídricos. Nesse contexto, o WF da província de Van, que é a região árida localizada mais a leste da Turquia, foi calculado de 2004 a 2019. A área de estudo cobre o lago Van, que é o maior lago da Turquia, e a bacia de Van, com uma área de 23,334 km² e uma população de 1.136 .757 (2019). Nos cálculos, as pegadas hídricas de safra $\left(W_{\text {crop }}\right)$, pecuária $\left(W_{F_{\text {livestock }}}\right)$ e doméstica e industrial ( $\left.\mathrm{WF}_{\text {domestictindustrial }}\right)$ foram avaliadas separadamente, e as pegadas hídricas azul e verde $\left(\mathrm{WF}_{\text {blue }}\right.$ e $\left.\mathrm{WF}_{\text {green }}\right)$ foram analisadas em detalhes. De acordo com os resultados, o WF médio da província de Van foi encontrado em 8,73 bilhões de $\mathrm{m}^{3}$ ano-1. Em toda a província, 87,6\% do WF são compostos por $\mathrm{WF}_{\text {crop }}, 4,9 \%$ são $\mathrm{WF}_{\text {livestock }}$ e 7,5\% são $\mathrm{WF}_{\text {domestictindustrial. }}$ Do $\mathrm{WF}_{\text {crop, }}, 62,5 \%$ dependem do $\mathrm{WF}_{\text {blue }}$, ou seja, de água doce. A maior parte do gado $\mathrm{WF}_{\text {livestock }}$ era composto por gado leiteiro (49\%) e ovelhas (38\%). O WF $\mathrm{F}_{\text {domestictindustrial }}$ médio de 2004 a 2019 foi de 0,64 bilhão de $\mathrm{m}^{3}$ ano $^{-1}$. A pegada hídrica per capita média da província de Van foi encontrada em $889,9 \mathrm{~m}^{3} \mathrm{ano}^{-1}$ capita $^{-1}$. Além disso, a região é classificada como grave escassez de água (257\%). Este estudo é um dos primeiros cálculos de WF baseados em províncias na Turquia e é o primeiro estudo a trazer um aspecto diferente para a literatura publicada, incluindo a umidade residual do solo dos meses de inverno. Como resultado deste estudo, o $\mathrm{WF}_{\text {blue }}$ do $\mathrm{WF}_{\text {crop }}$ está acima da média mundial e deve ser reduzido alterando o padrão de cultivo ou sincronizando as datas de plantio
\end{abstract}

*e-mail: caneryerli@yyu.edu.tr

Received: March 12, 2021 - Accepted: June 01, 2021

This is an Open Access article distributed under the terms of the Creative Commons Attribution License, which permits unrestricted use, distribution, and reproduction in any medium, provided the original work is properly cited. 
e colheita das safras para um período que se beneficie da precipitação. Além disso, espera-se que este estudo contribua para novos estudos para o cálculo da escala provincial WF e terá efeitos positivos no planejamento agrícola, alocação de água e a sustentabilidade dos recursos hídricos.

Palavras-chave: sustentabilidade agrícola, água azul, água verde, pegada hídrica, sustentabilidade hídrica.

\section{Introduction}

The freshwater resources on earth have significantly reduced due to global warming caused by anthropogenic effects, such as uncontrolled industrialization and urbanization, excessive fossil fuel consumption and insensitivity to the environment (Cakmak et al., 2007; Song et al., 2018; Awange, 2021). Many studies have pointed out that water will be scarce in the future and accordingly, production will decrease and humanity will face economic problems (Calzadilla et al., 2011; Ercin \& Hoekstra 2014; Hoekstra, 2014; Damania, 2020). In addition, the unconscious use of water-increasing water demand - as the population increases, adds to the severity of the pressure on water resources day by day (Sensoy et al., 2007; Sahin et al., 2016). Since the amount of water resources cannot be increased, protection and sustainability of water resources is a must. Urban, basin-oriented and global-scale integrated studies should be conducted to reduce the risk of water scarcity (Mekonnen and Hoekstra, 2016), and according to the results obtained in these studies, the development of strategies can only be achieved by managing water resources (Zeng et al., 2012). Management of water resources would only be possible through effective and planned water utilization, water quality controls (Bortolini et al., 2018), improvement of water distribution and operational efficiency, conservation of water resources, waste management and reduction of unnecessary irrigation (Yerli et al., 2019a) water productivity should be increased (Vanham and Mekonnen, 2021).

The concept of water footprint, which has been recently introduced to published literature is aimed at water resource management (Hoekstra, 2003; Ge et al., 2011; Galli et al., 2012; Morillo et al., 2015; Muratoğlu, 2019). The water footprint includes the measurement of the water volume required to produce certain goods or services, or to conduct the entire chain of production from raw material processing to consumption (Chico et al., 2013; Brindha, 2017). Water footprint is an approach that reveals the significance of water to the economy with the current consumption of society and allows environmental, economic and social analysis on various scales. Water consumption during the production of any product, any process, or any urban can be calculated with the water footprint approach.

Because water footprint is a new concept (Adetoro et al., 2021), the current unavailability of the required data (Ewaid et al., 2019), the high data requirement and the complexity of analyses, studies on water footprint are quite limited (Muratoglu, 2019). Generally, the studies have been conducted on countries and basins, and estimated data, general climatic inputs and major crop products have been used as the study data to conduct low resolution calculations (Chapagain and Hoekstra, 2004; Aldaya et al., 2010; Mekonnen and Hoekstra, 2011a; Zhang and Anadon, 2014). However, due to the fact that the agricultural water footprint constitutes a large portion of the total water footprint, that climate and regional conditions play a significant role in agricultural production and water distribution and consumption vary based on regional characteristics (Mekonnen and Hoekstra, 2014: Zhuo et al., 2014), urban water footprint comes to the fore (Vanham et al. 2014; Paterson et al. 2015; Degefu et al. 2018). Furthermore, since the vast majority of the global population live in cities and the number of urban dwellers continuously increases, the importance of urban water footprint calculations is quite important (Aerts et al., 2009). In addition to, water footprint, which allows numerical analysis, will pioneer the distribution and comparative analysis of water use in these sectors, the green and blue water utilization rates, and the water management and planning stages (Yerli et al., 2019b).

The aim of the present study was to calculate and analyze the production water footprint in Van province covers the Van basin and delivering water resources to different regions, including all the districts of the province. In this context, crop and livestock production, and domestic and industrial water utilization were evaluated separately, and the blue and green water footprint figures were calculated. In adittion, per capita water footprint was also analyzed to compare to other different studies. The main research questions of the study were as follows: What are the water footprints for different production sectors and their share in the province? What is the water footprint and virtual water content of significant crops in the province? What is the effect of water footprint on the sustainability of blue water in arid regions and water consumption for the future? How is the agricultural water footprint affected in arid regions compared to other regions? What is the effect of the trends in the water footprint over time in an area that is constantly changing?

Although Van province provides indispensable production of crops and ranks first in Turkey in terms of small ruminants, there is no comprehensive research regarding water resources. This study is one of the first studies that analyzed the urban water footprint in detail not just in Van but also in Turkey, and it is also the first study contributing to published literature from a different point of view by calculating the water footprint of crop production with high and reliable data inputs that considered the residual soil moisture from winter months. The advantages of the present study compared to other water footprint studies included working in a specific area, the use of up-to-date data accepted by national and international authorities, and benefits from a wide time period (2004 to 2019). In addition, the wide ranging diversity of crops cultivated in the province, their properties and effective root depths, soil properties and water holding capacity of the soils, residual soil moisture from the winter months and the effective precipitation (the average precipitation 
for many years) were used to calculate the water footprint for crop production. As a result, the study approach was more original and realistic. The study is expected to increase efficiency and sustainability of water resources with better planning in arid and semi arid provinces such as the Van province, and to pave the way for new studies.

\section{Material and Methods}

\subsection{Study area}

Located in the Eastern Anatolia region of Turkey, Van province is one of the largest and most developed provinces (Figure 1). The surface area of Van is $23.334 \mathrm{~km}^{2}$ and $2.86 \%$ of the total land mass of Turkey. With this area, Van province constitutes a larger area than the Van Lake basin, which is one of Turkey's 26 basins. The altitude of the province, located at $38^{\circ} 29^{\prime} 39^{\prime \prime}$ North latitude and $43^{\circ} 22^{\prime} 48^{\prime \prime}$ East longitude, is approximately $1725 \mathrm{~m}$. The total population of Van province was 942.771 in 2004 and 1.136 .757 in 2019 according to data from the Turkish Statistical Institute (TSI, 2020), and has increased by approximately $21 \%$ over 15 years. The vast majority of the population is employed in agriculture and trade Industrial activities are almost non-existent in the province (Kanberoglu, 2016). Crop and livestock production are the main income sources. The Van province ranks first in Turkey in terms of small ruminant assets (TSI, 2020).

In Van province, where the terrestrial climate is dominant, winters are cold and summers are dry with little rainfall, although the number of frosty days is high throughout the year. However, climatic conditions are temperate due to the microclimate effect created by Lake Van, located in the center of the province. According to the long term meteorological reports from 1976 to 2019-from six different climate stations selected to represent the region-obtained from the Turkish State Meteorological Service, the annual average air temperature was $9.1^{\circ} \mathrm{C}$, the average relative humidity was $54 \%$, the total hours of sunshine was 94.8, the total evaporation was $1397.6 \mathrm{~mm}$ and the total precipitation was $387.5 \mathrm{~mm}$ (TSMS, 2020). According to the averages from the six climate stations, the monthly total and effective precipitation, and the average air temperature values are given in Figure 2. Accordingly, the total precipitation and average temperature were $27.2 \mathrm{~mm}$ and $20.5^{\circ} \mathrm{C}$ in the active crop production season (June-July-August). Inadequate precipitation and high temperatures led to the need for irrigation to achieve high yields.

Approximately $60 \%$ of the agricultural soil in the province consists of sandy clay loam, and the rest consists of sandy loam and sandy clay textures, i.e., medium-texture soils (Tufenkci et al., 2009). Approximately $24 \%$ of the agricultural area of the province is shallow and the rest has deep soil (Karaca et al., 2019). Van province has $3744 \mathrm{~km}^{2}$ of agricultural land, and the amount of irrigated land is $1164 \mathrm{~km}^{2}$.

\subsection{Method}

The water footprint requires a high level of data input (Muratoglu, 2019). When calculating the water footprint for a certain area, the accuracy of the results is closely associated with the quality of the data entered (Godar et al., 2015). In the present study, current and realistic data over a long time period (2004 to 2019) were used instead of estimated data, and many national and international databases were used.

In this study, water footprint calculations were made according to the water footprint method developed by Hoekstra et al. (2011). The total water footprint of an area $\left(\mathrm{WF}_{\text {total }}\right)$ consists of the water footprint for crop production $\left(\mathrm{WF}_{\text {crop }}\right)$, the water footprint for livestock production $\left(\mathrm{WF}_{\text {livestock }}\right)$, and the domestic and industrial water footprint $\left(\mathrm{WF}_{\text {domestictindustrial }}\right)$ (Equation 1) (Muratoglu, 2019). The most important component of $\mathrm{WF}_{\text {total }}$ is the $\mathrm{WF}_{\text {crop }}$ due to intense water consumption (Lovarelli et al., 2016). $\mathrm{WF}_{\text {livestock }}$ constitutes the amount of water consumed by the livestock in the region (Mekonnen and Hoekstra, 2012). $\mathrm{WF}_{\text {domestictindustrial, }}$ which is usually the smallest component in the total water footprint (Klemeš, 2015), is the water volume consumed by individuals during domestic and industrial activities. The flow diagram used in the calculation of $\mathrm{WF}_{\text {total }}$ for Van province is given in Figure 3.

$$
W F_{\text {total }}=W F_{\text {crop }}+W F_{\text {livestock }}+W F_{\text {domestic }+ \text { industrial }}
$$
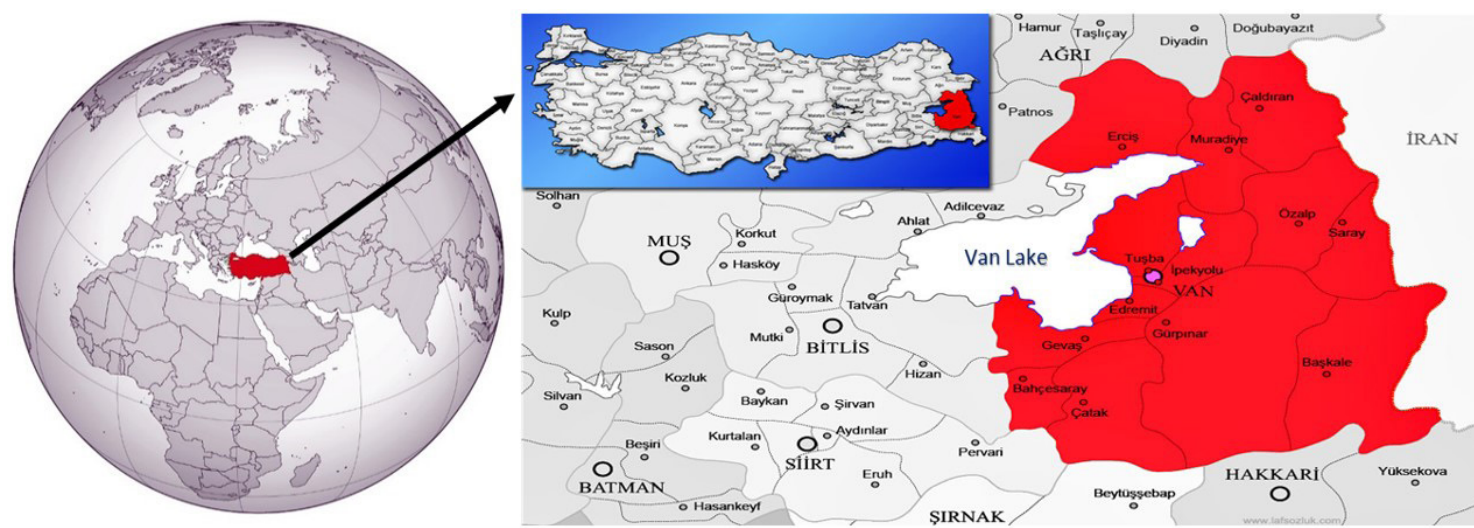

Figure 1. The study area. 


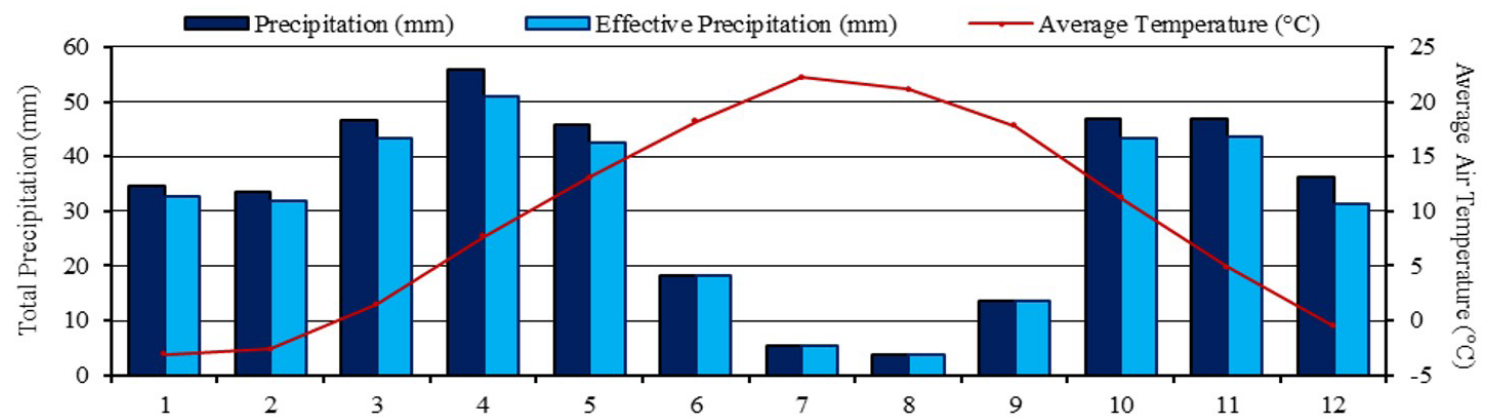

Figure 2. Monthly average air temperature, total and effective precipitation values in Van.

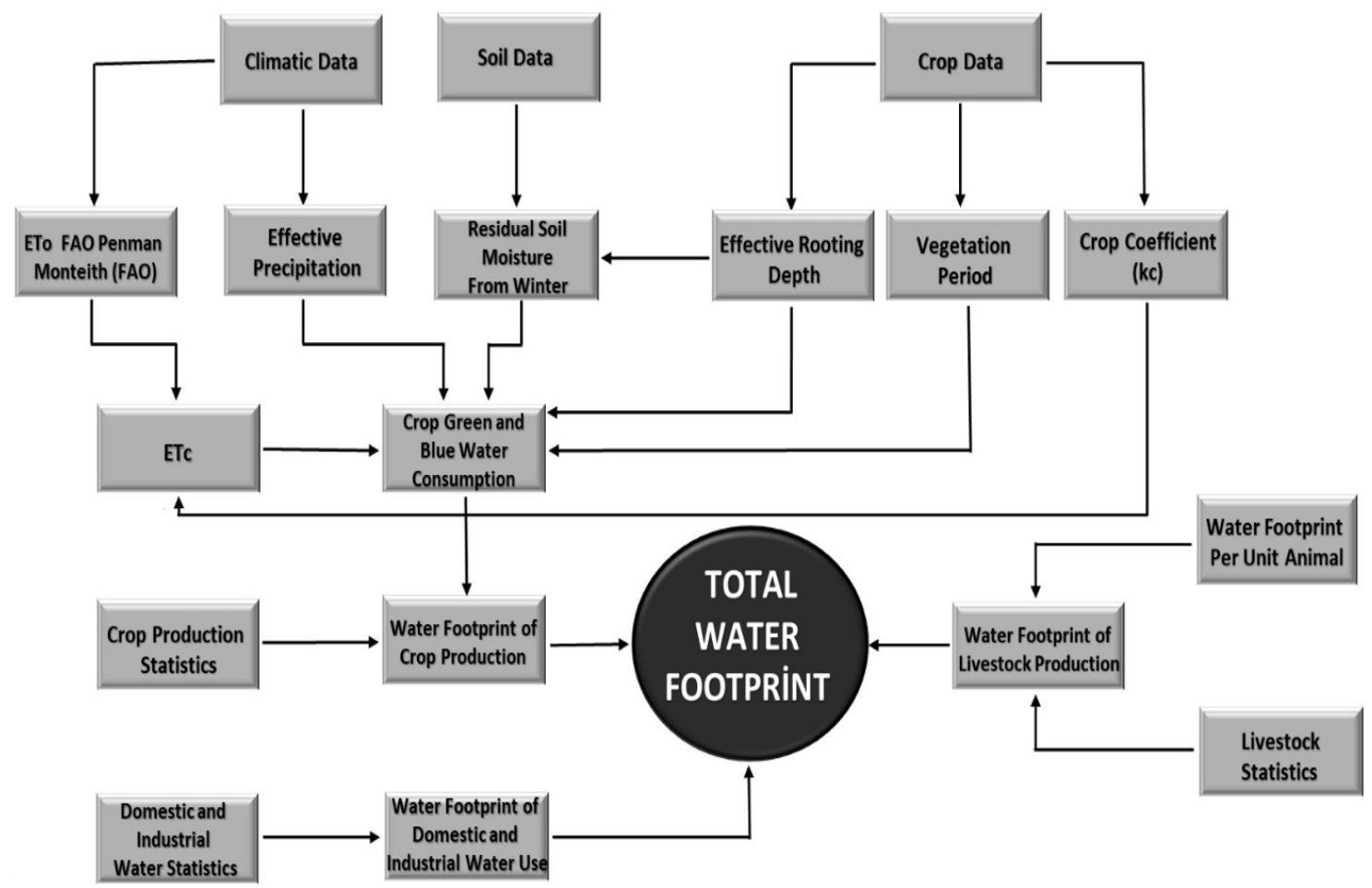

Figure 3. Flow diagram for calculation of $\mathrm{WF}_{\text {total }}$ in Van province.

\subsection{Water footprint analysis of crop production}

The amount of $\mathrm{WF}_{\text {crop }}$ for a region depends on evapotranspiration $\left(E T_{c}\right.$ ). $\mathrm{ET}_{c}$, which can be defined as the water requirement of the crops, changes depending on the region's climate conditions, soil properties and crop characteristics (Allen et al., 1998). The part of ET for the crop that is met by effective precipitation, $\left(\mathrm{P}_{\text {eff }}\right)^{\mathrm{C}}$, constitutes the green water amount for the crop $\left(\mathrm{ET}_{\text {green }}\right)$, and the remaining part is the irrigation requirement, i.e., the amount of blue water for the crop $\left(\mathrm{ET}_{\text {blue }}\right)$ (Hoekstra et al., 2011). When the effective precipitation $\left(\mathrm{P}_{\text {eff }}\right)$ is more than the crop evapotranspiration $\left(\mathrm{P}_{\text {eff }}>\mathrm{ET}_{\mathrm{c}}\right)$, the irrigation requirement is eliminated, and by contrast, when $\mathrm{P}_{\text {eff }}<\mathrm{ET}_{\mathrm{c}}$, the net irrigation requirement of the crops is determined as the evapotranspiration minus the effective precipitation $\left(\mathrm{ET}_{\mathrm{c}}-\mathrm{P}_{\text {eff }}\right.$ ) (Equations 2 and 3) (Muratoglu,
2019). In order to determine the $\mathrm{ET}_{c}$ values for all crops, the reference crop water consumption ( $\mathrm{ET}_{0}$ ) values calculated by the FAO-Penman Monteith approach for each ten days during growing periods. These were corrected with crop coefficients $(\mathrm{kc})$ to calculate crop evapotranpirations $\left(\mathrm{ET}_{\mathrm{c}}=\mathrm{ET} \times \mathrm{kc}\right) . \mathrm{ET}_{c}$ values calculated with this approach for the studied region were obtained directly from the last and current study (Turkey Irrigated Crop Water Consumption Guide) by the Turkish Ministry of Agriculture and Forestry (TAGEM, 2017). Planting-harvesting dates and vegetation periods of the crops were also obtained from the same study. In the daily $\mathrm{ET}_{0}$ calculations in the guide mentioned, the data from the last 30 years, daily average, minimum and maximum temperatures, relative humidity, wind speed, hours of sunshine and sunshine intensity were considered. The scientific results of different field trials conducted in 
Turkey and the study region, the data at the international level, graduate theses and other scientific publications and FAO-56 data were all used to obtain favorable kc values (Allen et al., 1998; TAGEM, 2017).

$$
\begin{aligned}
& E T_{\text {green }}=\min \left(E T_{c}, P_{\text {eff }}\right) \\
& E T_{\text {blue }}=\max \left(0, E T_{c}-P_{\text {eff }}\right)
\end{aligned}
$$

The benefit that crops can obtain from total precipitation can be defined as $\mathrm{P}_{\text {eff }}$ (Aldaya \& Llamas, 2008). Using the approach developed by the United States Department of Agriculture, Soil Conservation Service (USDA, 1993), monthly $\mathrm{P}_{\text {eff }}$ values were calculated with CROPWAT 8.0 software, and all precipitation below $25 \mathrm{~mm}$ was accepted as $\mathrm{P}_{\text {eff }}$ based on the same approach. In the water footprint studies in literature, $\mathrm{P}_{\text {eff }}$ was included only in the the crop planting-harvest periods. However, at the time of planting, moisture in the soil (residual soil moisture from winter $)\left(\mathrm{P}_{\text {winter }}\right)$ could be used by the crops for germination and during the initial growing periods (Kanber, 2010). Especially in regions such as the Van province, where it is arid and the water resources are inadequate, irrigation is not possible at the time of planting, and $\mathrm{P}_{\text {winter }}$ enables germination of the crops. $\mathrm{P}_{\text {winter }}$ is the amount of moisture retained in soil from the winter months at the beginning of the growth period of the crops. $\mathrm{P}_{\text {winter }}$ was calculated from the amount of moisture that the soil can hold. Retained rates of precipitation from winter months were obtained from the study conducted by Kanber (2010) from different regions of Turkey for every winter month. Every two weeks, a correlation was made using the assumption that there is a linear relationship between the amount of moisture retained in the soil over two months. $P_{\text {winter }}$ was determined by using this rate and finally the $\mathrm{P}_{\text {winter }}$ value obtained was added to the total $\mathrm{P}_{\text {eff }}$ in the vegetation period. In the present study, the water holding capacities were considered to relate to each crops's effective root depth. The water holding capacities of non-problematic soils were determined according to soil texture (Tufenkci et al., 2009), soil depths (Karaca et al., 2019) and the effective root depth of the crops obtained from the FAO database (FAO, 2018).

$\mathrm{WF}_{\text {crop }}$ calculations were done for the twenty-one most cultivated crops (barley, green and dry beans, chickpeas, green lentils, potatoes, silage corn, sugar beet, alfalfa, sainfoin, cabbage, grapes, apples, apricots, strawberrys, melon, watermelon, tomatoes, eggplants and onions). Production volumes and the amount of production areas for these crops were obtained from the Turkish Statistical Institute (TSI, 2020). Average yield values (ton/da) were obtained by dividing the production volume of each crop by the amount of production area.

Finally, the $\mathrm{ET}_{\text {green }}$ and $\mathrm{ET}_{\text {blue }}$ values and the average yield values $(\mathrm{Y})$ for each crop in the province were used to calculate the $\mathrm{WF}_{\text {crop }}$ (Equations 4 and 5) (Muratoglu, 2019). The water consumption volume during crop production was calculated as the per unit volume $\left(\mathrm{m}^{3}\right.$ ton $\left.^{-1}\right)$, and this process was applied to all crops used, while the blue and green water footprints $\left(\mathrm{WF}_{\text {blue }}\right.$ and $\left.\mathrm{WF}_{\text {green }}\right)$ were found separately. By collecting $\mathrm{WF}_{\text {blue }}$ and $\mathrm{WF}_{\text {green }}$ for each crop, the water footprint of a crop was determined (Equation 6 ), and by collecting the water footprints of all crops, the total $\mathrm{WF}_{\text {crop }}$ for Van province was obtained (Equation 7) (Muratoglu, 2019).

$$
\begin{gathered}
W F_{\text {green }}\left(m^{3} \text { ton }^{-1}\right)=\frac{\text { ETgreen }(\mathrm{mm})}{Y(\text { ton } / d a)} \\
W F_{\text {blue }}\left(m^{3} \text { ton }^{-1}\right)=\frac{\operatorname{ETblue~}(\mathrm{mm})}{Y(\text { ton } / d a)} \\
W F\left(m^{3} \text { ton }^{-1}\right)=W F_{\text {green }}\left(m^{3} \text { ton }^{-1}\right)+W F_{\text {blue }}\left(m^{3} \text { ton }^{-1}\right) \\
W F_{\text {crop }}=\left[W_{\text {barley }}+W F_{\text {potato }}+\ldots+W F_{\text {eggplant }}+W F_{\text {apple }}\right] \text { (7). }
\end{gathered}
$$

\subsection{Water footprint analysis of livestock production}

The vast majority of water consumed in the $\mathrm{WF}_{\text {livestock }}$ consists of water used in the production of feed crops, while the rest is the drinking water consumed by the livestock and the indirect water consumption. Water consumed for the production of feed crops is included in $\mathrm{WF}_{\text {crop }}$ (Mekonnen and Hoekstra, 2012). However, there are also studies in literature where the production of feed crops is included in $\mathrm{WF}_{\text {livestock }}$ (Muratoglu, 2019, 2020).

In the current study, blue water footprints for animals were evaluated instead of animal products such as meat, milk and eggs. The calculation of $\mathrm{WF}_{\text {livestock }}$ was conducted with global average data because regional data were not available. Average data on a global scale for beef cattle, dairy cattle, goat, sheep, poultry (including broiler and layer chickens, turkey, goose and duck) and horse (including donkey and camel) were obtained from published literature (Mekonnen and Hoekstra, 2012). Data on the number of livestock obtained from TSI (2020) was multiplied by the annual water consumption $\left(\mathrm{m}^{3} \mathrm{year}^{-1}\right)$ of a animal to calculate $\mathrm{WF}_{\text {livestock. }}$. Gray water is not included in $\mathrm{WF}_{\text {livestock }}$ because there is no available data on the gray water footprint.

\subsection{Domestic and industrial water footprint analysis}

The domestic water footprint of an area includes blue water consumption by the domestic activities of individuals living in that area (Chapagain and Hoekstra, 2004). The industrial water footprint is the water consumed in industrial activities. Gray water is an important concept in regions where industrial activities are intense. However, in regions with low industrial capacity, gray water footprint does not need to be included in the total water footprint calculations (Chapagain and Hoekstra, 2004; Hoekstra et al., 2011; Muratoglu, 2019, 2020). Therefore, since the industrial activities in Van province are low (Kanberoglu, 2016), the gray water footprint was not evaluated, and the industrial and domestic water footprint were analyzed together. For this purpose, the data obtained from TSI (2020) was utilized, and $\mathrm{WF}_{\text {domestictindustrial }}$ was found by multiplying the amount of water consumption per capita in the districts by the number of people residing in the districts from 2004 to 2019. 


\subsection{Blue water scarcity}

The importance of blue water for regions with insufficient water resources or for arid regions is clear. Therefore, many different methods are used and developed to identify and understand the water resources, especially in these regions. However, flow requirements and real run-off amounts are usually ignored in the studies related to the sustainability of fresh water (Mekonnen \& Hoekstra, 2011b), but the approach of Hoekstra et al. (2012) provides a different perspective. Because, according to other water analyses, blue water is used instead of using water withdrawal, environmental flow requirements and employing natural undepleted run-off (Muratoglu, 2019). The sustainability of blue water in the study area was determined using this approach. Accordingly, blue water scarcity $\left(\mathrm{WS}_{\text {blue }}\right.$ ) was obtained by assessing $\mathrm{WF}_{\text {blue }}$ in the region in proportion to blue water availability $\left(W_{\text {blue }}\right)$ (Equation 8). WA $_{\text {blue }}$ was defined as the natural runoff amount minus the environmental flow requirements. The natural runoff value was calculated by summing the real runoff and $\mathrm{WF}_{\text {blue }}$ in the region. The real runoff value of the Van province was obtained from the study of Mekonnen and Hoekstra (2011b). The environmental flow requirement was taken to be $80 \%$ of natural runoff, as Hoekstra et al. (2011) proposed. The result obtained was classified as low $\left(\mathrm{WS}_{\text {blue }}<100 \%\right)$, moderate $\left(100<\mathrm{WS}_{\text {blue }}<150 \%\right)$, significant $\left(150<\mathrm{WS}_{\text {blue }}<200 \%\right)$ and severe $\left(\mathrm{WS}_{\text {blue }}>200 \%\right)$ water scarcities (Hoekstra et al., 2012).

$$
W S_{\text {blue }}=\frac{\text { WFblue }}{\text { WAblue }} \times 100
$$

(Equation 8).

\section{Results and Discussion}

In this study, in which the $\mathrm{WF}_{\text {total }}$ for the years 2004 to 2019 was calculated in the Van province, the average annual water footprint was found to be 8.73 billion $\mathrm{m}^{3}$. Of this, $87.6 \%$ ( 7.66 billion $\left.\mathrm{m}^{3}\right), 4.9 \%\left(0.43\right.$ billion $\left.\mathrm{m}^{3}\right)$ and $7.5 \%$ $\left(0.64\right.$ billion $\mathrm{m}^{3}$ ) of the $\mathrm{WF}_{\text {total }}$ consisted of $\mathrm{WF}_{\text {crop }}, \mathrm{WF}_{\text {livestock }}$ and $\mathrm{WF}_{\text {domestictindustrial }}$, respectively. $62.5 \%$ and $37.5 \%$ of this $\mathrm{WF}_{\text {crop }}$ corresponded to $\mathrm{WF}_{\text {blue }}$ and $\mathrm{WF}_{\text {green }}$ (Figure 4). On a global scale the $\mathrm{WF}_{\text {total }}$ calculations by Mekonnen and Hoekstra (2011c) showed that production was found to be based on $\mathrm{WF}_{\text {green. }}$. However, the opposite situation was observed for Van province. As expected, $\mathrm{WF}_{\text {crop }}$ created the largest water volume in the province, and the vast majority of $\mathrm{WF}_{\text {crop }}$ was based on $\mathrm{WF}_{\text {blue }}$. It was clear that this situation was due to the increase in the need for irrigation water because of low annual precipitation in the province as well as the amount of precipitation falling during the crop development period, which was also very low (Figure 2).

\subsection{Per capita water footprint}

The per capita water footprint values are the best approach (Muratoglu, 2020) for a comparison with the water footprints of different regions (Cheng et al., 2019). The per capita water footprint in developed regions are in the range of 1250 to $2850 \mathrm{~m}^{3}$. The average per capita water footprint of the Van province between 2004 and 2019 was found to be $1385 \mathrm{~m}^{3}$ year $^{-1}$ capita $^{-1}$ and is lower than the world average, which was $1385 \mathrm{~m}^{3}$ year $^{-1}$ capita $^{-1}$ (Hoekstra and Mekonnen, 2012), and the average in Turkey, which was $1642 \mathrm{~m}^{3}$ year-1 $^{-1}$ capita $^{-1}$ (Pegram et al., 2014) between 2000 and 2011. When the per capita water footprint of Van and other countries we are examined, it was seen that Van has a very low water footprint like other arid areas. This is related to the volume of consumption, consumption pattern (Liu et al., 2008), the impact of the climate and agricultural practices (Chapagain et al., 2006). It is also thought that high migration rate from different regions to Van creates a rapidly increasing population that has a high impact on it.

When the per capita water footprints in the study were analyzed, it was seen that the lowest value was in 2009 and the highest value was in 2012 (Figure 5). This situation is closely related to the drought experienced in 2009 and the high precipitation experienced in 2012 (TSMS, 2020). Per capita water footprints in the province were not consistent after 2009 where the sudden decline of some products with high water consumption, such as chickpeas, lentils and grapes in the province (TSI, 2020), had an effect on the per capita water footprints. In addition, the increase in out-migration since 2010 and the decrease in the population (TSI, 2020) are considered to be important in the increase in the water footprint as of 2010.

\subsection{Water footprint of crop production}

In the agricultural sector, which has higher water consumption than other sectors (Mancosu et al., 2015; Karci and Ucar 2019), the majority of freshwater is used

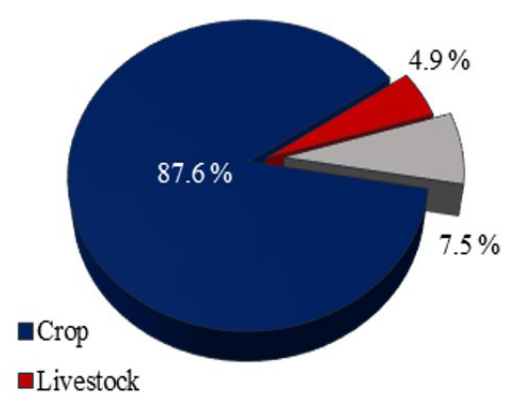

口Domestic+industrial

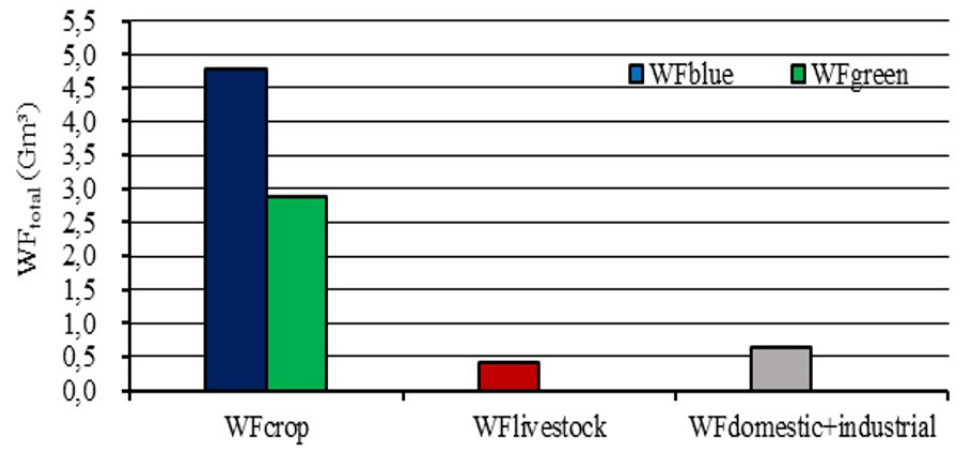

Figure 4. Distribution of $\mathrm{WF}_{\text {total }}$ in Van province. 
for irrigation of crops (Galan-Martin et al., 2017). Especially in arid and semi-arid regions, more irrigation water is needed, i.e., blue water. In Van province, $87.6 \%$ of the $\mathrm{WF}_{\text {total }}$ consisted of $\mathrm{WF}_{\text {crop }}$, and this was supported by similar studies (Chapagain and Hoekstra, 2004; Aldaya and Llamas, 2008; Hoekstra and Mekonnen, 2012; Muratoglu, 2019, 2020). The $\mathrm{WF}_{\text {blue }}$ and $\mathrm{WF}_{\text {green }}$ components of $\mathrm{WF}_{\text {crop }}$ were found to be 4.81 billion $\mathrm{m}^{3}$ and 2.85 billion $\mathrm{m}^{3}$, respectively. While $75 \%$ of the $\mathrm{WF}_{\text {crop }}$ consisted of $\mathrm{WF}_{\text {green }}$ on average in Turkey (Mekonnen and Hoekstra, 2011a), 78\% of the $\mathrm{WF}_{\text {crop }}$ consisted of $\mathrm{WF}_{\text {green }}$ on average, worldwide (Mekonnen and Hoekstra, 2011c). The $\mathrm{WF}_{\text {green }}$ of $\mathrm{WF}_{\text {crop }}$ was found to be $37.5 \%$ in the Van province and this led to the conclusion that the demand for blue water for crop production was high. The demand for freshwater increases as a result of the high evapotranspiration combined with insufficient precipitation during the crop producing season (Siebert and Döll, 2010). High $\mathrm{WF}_{\text {blue }}$ values restrict agricultural production, especially in regions with poor water resources (Mali et al., 2018). $\mathrm{WF}_{\text {blue }}$ is a risk factor that predicts water scarcity in the future. For this reason, having $\mathrm{WF}_{\text {green }}$ higher than $\mathrm{WF}_{\text {blue }}$ is very important for the sustainability of water resources (Novoa et al., 2019).
The average virtual water content per crop in Van province was $478.3 \mathrm{~m}^{3}$ ton $^{-1}$, and is given in Figure 6 as $\mathrm{WF}_{\text {blue }}$ and $\mathrm{WF}_{\text {green }}$ for each crop. Accordingly, the $\mathrm{WF}_{\text {blue }}$ of all crops except for onions is more than $\mathrm{WF}_{\text {green }}$. This situation is a result of insufficient precipitation in the province during the vegetation period. The reason why the onion $\mathrm{WF}_{\text {green }}$ is more than the $\mathrm{WF}_{\text {blue }}$ is related to the crop's abundant use of precipitation as a result of the early planting date (15 May) and short vegetation period (75 days). The crop with the highest water footprint in the province is chickpeas, which have been found to have a high virtual water content in many studies (Chapagain and Hoekstra, 2004; Gupta, 2008; Mohammadi-Kanigolzar et al., 2014), while the lowest is cabbage. The $\mathrm{WF}_{\text {green }}$ and $\mathrm{WF}_{\text {blue }}$ of chickpeas, which have the highest amount of green water, are almost equal to each other. Lentils, beans (green), chickpeas, apples, grapes and walnuts are crops with the highest $\mathrm{WF}_{\text {blue }}$ values in the province, respectively. As Fu et al. (2018) stated, the crops that have high yields according to other regions, also have a high virtual water content. In addition, Pegram et al. (2014) stated that the water footprint of fruits is generally found to be higher than vegetables.

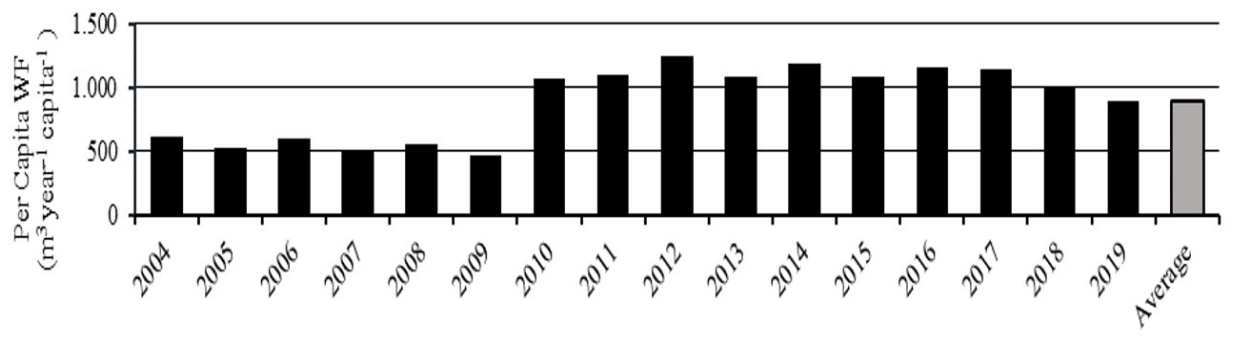

Figure 5. Per capita water footprint between 2004-2019 in Van province.


Figure 6. The $\mathrm{WF}_{\text {crop }}$ of Van province per crop. 
The $\mathrm{WF}_{\text {green }}$ and $\mathrm{WF}_{\text {blue }}$ values of crop products, which are important in terms of production capacity in the Van province are compared with the Upper Tigris River Basin, the worldwide average and the Turkish average, and are graphically illustrated in Figure 7. The $\mathrm{WF}_{\text {green }}$ and $\mathrm{WF}_{\text {blue }}$ values for apricots, tomatoes and cabbage in Van province are similar to the worldwide average. It was seen that the Van and worldwide average $\mathrm{WF}_{\text {green }}$ values for chickpeas, potatoes, sugar beet, watermelons, eggplants and onions were similar. In particular the $\mathrm{WF}_{\text {green }}$ values for beans (green), lentils and barley in Van are well below the worldwide average, and the $\mathrm{WF}_{\text {blue }}$ value for chickpeas, apples, beans (green) and lentils were found to be well above the worldwide average. In general, the $\mathrm{WF}_{\text {green }}$ and $\mathrm{WF}_{\text {blue }}$ values for the crops in Van province are similar to the worldwide average, but the total water footprints of some crops (chickpeas, apples and grapes) are found to be much higher. This situation may be related to crops with high water footprints that have low yields in the region (Mekonnen and Hoekstra, 2010). In the comparison of the $\mathrm{WF}_{\text {green }}$ for Turkey and for Van province, it was seen that the $\mathrm{WF}_{\text {green }}$ for barley is higher in Turkey, and the $\mathrm{WF}_{\text {blue }}$ is similar, while $\mathrm{WF}_{\text {green }}$ and $\mathrm{WF}_{\text {blue }}$ for grapes and beans (green) are higher in Van province. The $\mathrm{WF}_{\text {green }}$ and $\mathrm{WF}_{\text {blue }}$ values for silage corn (except $\mathrm{WF}_{\text {green }}$ ), potatoes, sugar beet and tomatoes in Van province are relatively similar to the Turkish average. The main reason for these similarities and differences arises from the differences due to soil distribution and water resources (Sun et al., 2013) and especially to climate (Mekonnen and Hoekstra, 2011a). In addition, the $\mathrm{WF}_{\text {crop }}$ values for the Upper Tigris River Basin, located to the south of the study area, is compared to the Van province. Accordingly, $\mathrm{WF}_{\text {green }}$ for crop production in Van province is found to be higher for almost all crops. The reason for this is due to the inclusion of residual soil moisture from winter when calculating the $\mathrm{WF}_{\text {crop }}$ for Van, i.e., the difference in method. $\mathrm{WF}_{\text {green }}$ and $\mathrm{WF}_{\text {blue }}$ values for onions and sainfoin showed similarity between the two regions, and the $\mathrm{WF}_{\text {blue }}$ value for barley, clover, apricots, melons, watermelons, tomatoes and eggplants were lower in Van province. This situation can be explained by differences in the irrigation regime of the regions (Boelens and Vos, 2012), the differences in the crop varieties and variability of water requirements depending on the climatic differences of the regions. To summarize the $\mathrm{WF}_{\text {crop }}$ for the Van province, it is possible to say that there are some changes in evaluation compared to other different studies, but in general, these changes diverge according to the regional conditions (Fader et al., 2010) and are in good agreement with other studies.

\subsection{Water footprint for livestock production}

The volume of water consumed directly or indirectly by animals during the production of meat, milk, eggs and other products can be defined as $\mathrm{WFl}_{\text {ivestock }}$ (Bosire et al., 2017; Ibidhi et al., 2017). In Van province, $W_{\text {livestock }}$ has been found to be 0.43 billion $\mathrm{m}^{3}$ and constitutes $4.9 \%$ of the $\mathrm{WF}_{\text {total }}$ Cattle, which have the highest water footprint in the province (Figure 8), increased its water footprint. Because the per calorie water footprint of beef corresponds to nearly 20 times that of cereals (Hoekstra, 2012), high meat consumption in any region may increase the water footprint of that region (Chapagain and Hoekstra, 2004). Similar results were obtained with Hoekstra (2012), who stated that more than half of the $\mathrm{WF}_{\text {livestock }}$ value is made up of cattle on a global scale. The annual water consumption of dairy cattle is almost 30 times higher than that of sheep (Mekonnen and Hoekstra, 2012). Dairy cattle come to the fore in terms of water footprint because of this, even though the number of sheep is far greater than dairy cattle in Van province. The reason for the low water consumption of goats and poultry is associated with their lower annual water consumption ( 32 and $33 \mathrm{~m}^{3}$ year $^{-1}$ capita $^{-1}$ ) compared to other livestock (Hoekstra, 2012).

When the $\mathrm{WF}_{\text {livestock }}$ of Van province was analyzed by year, it was seen that the lowest value was in 2012 and the highest value was in 2017 (Figure 8). The reason for the increase in 2017 is that 2017 featured the highest number of animals compared to all other years (TSI, 2020). The reason for the decrease of the $\mathrm{WF}_{\text {livestock }}$ value in 2012 was thought to be related to the major earthquake in September 2011, and accordingly to a decrease in the number of animals.

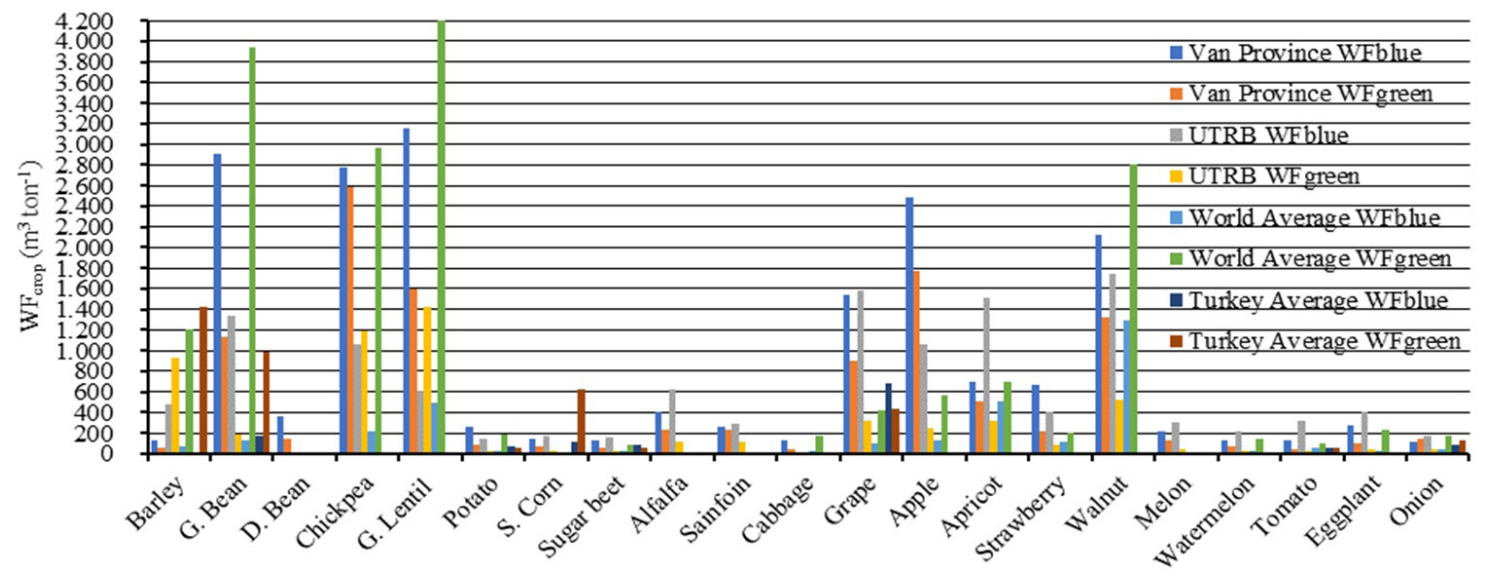

Figure 7. Comparison $\mathrm{WF}_{\text {blue }}$ and $\mathrm{WF}_{\text {green }}$ of $\mathrm{WF}_{\text {crop }}$ of the Van province with the Upper Tigris River Basin (Muratoglu, 2019), the worldwide average (Mekonnen and Hoekstra, 2011b) and the Turkish average (Mekonnen and Hoekstra, 2011a). 


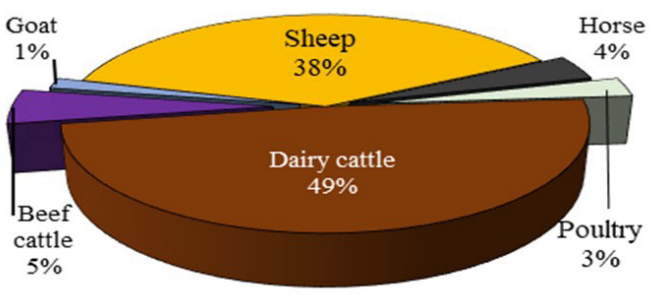

$\square$ Dairy cattle $\square$ Beef cattle $\square$ Goat $\square$ Sheep $\square$ Horse $\square$ Poultry

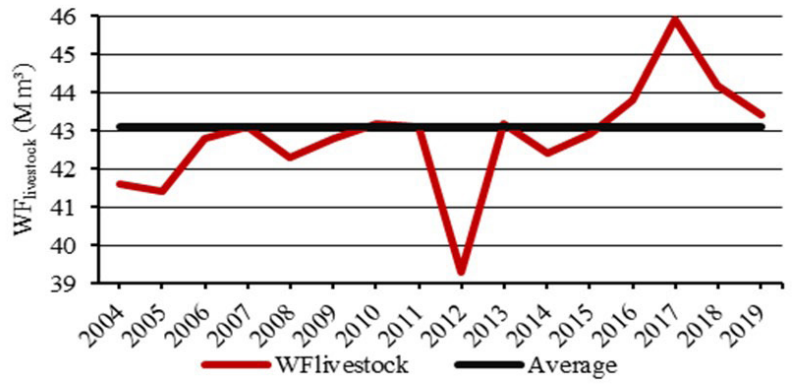

Figure 8. Distribution of $\mathrm{WF}_{\text {livestock' }}$ and $\mathrm{WF}_{\text {livestock }}$ by years in Van province.

Feed crops consumed by livestock animals correspond to approximately one third of the total $\mathrm{WF}_{\text {livestock }}$ value (Mekonnen and Hoekstra, 2011c). However, feed crops were not included in the $\mathrm{WF}_{\text {livestock }}$ value but were evaluated as part of $\mathrm{WF}_{\text {crop }}$ (Mekonnen and Hoekstra, 2012). If the production of feed crops for Van province was included in $\mathrm{WF}_{\text {livestock}}, 75.3 \%, 18.6 \%$ and $6.1 \%$ of the $\mathrm{WF}_{\text {total }}$ value are $\mathrm{WF}_{\text {crop }}, \mathrm{WF}_{\text {livestock }}$ and $\mathrm{WF}_{\text {domestic + industrial, respectively }}$ (Figure 9). This situation reveals that feed crops consume high amounts of water in Van province. Comparing the conditions in which feed crops were included and not included in $\mathrm{WF}_{\text {crop }}$, blue and green water distributions were almost unaffected $\left(\mathrm{WF}_{\text {blue }}: 65.2 \%\right.$ and $\left.\mathrm{WF}_{\text {green }}: 34.8 \%\right)$, Looking at $\mathrm{WF}_{\text {livestock }}$ under conditions in which feed crops were included in $\mathrm{WF}_{\text {livestock }}$, it was seen that $64.4 \%$ and $35.6 \%$ of $\mathrm{WF}_{\text {livestock }}$ consisted of $\mathrm{WF}_{\text {blue }}$ and $\mathrm{WF}_{\text {green }}$, respectively (Figure 9). Mekonnen and Hoekstra (2012) stated that $87 \%$ of the global $\mathrm{WF}_{\text {livestock }}$ value corresponded to $\mathrm{WF}_{\text {green' }}$, but in the Van province, livestock production dependent on blue water was carried out like crop production. When the values of Van province were compared with the Upper Tigris River Basin (Muratoglu, 2019) and Diyarbakır province (Muratoglu, 2020), it was seen that the crop, livestock and domestic-industrial water distributions were similar but that the $\mathrm{WF}_{\text {blue }}$ value within the $\mathrm{WF}_{\text {livestock }}$ value was higher in the Van province. This may be related to the use of high levels of blue water to increase the yield in the feed crops due to the high number of animals-in addition to being an arid region of Van province. When calculating $\mathrm{WF}_{\text {livestock }}$ for a region, considering that feed crops can be procured from other regions and also that ready-made feed may be used, the inclusion of feed crops in $\mathrm{WF}_{\text {crop }}$ will reveal more precise and realistic results.

\subsection{Domestic and industrial water footprint}

Water used in domestic needs and industrial activities make up $\mathrm{WF}_{\text {domestictindustrial }}$. The average $\mathrm{WF}_{\text {domestictindustrial }}$ of Van province between 2004 and 2019 was found to be 0.64 billion $\mathrm{m}^{3}$, and this value corresponded to $7.5 \%$ of the $\mathrm{WF}_{\text {total }}$. Figure 10 shows that domestic and industrial water use has been increasing steadily with increasing population, and this increase only decreased in 2012. It is thought that the reason for the decrease in 2012 was because of a population decrease due to political reasons. Because the Van province is one of the least industrialized regions in Turkey (Kanberoglu, 2016), it is estimated that

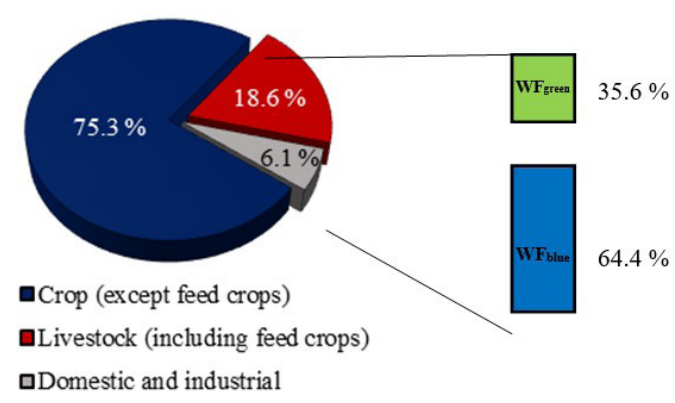

Figure 9. Distribution of $\mathrm{WF}_{\text {total }}$ in Van province when feed crops are included in $\mathrm{WF}$

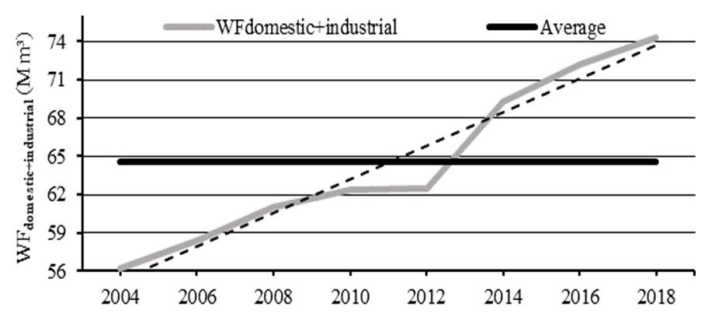

Figure 10. $\mathrm{WF}_{\text {domestictindustrial }}$ by years in Van province.

domestic water consumption is higher than industrial water consumption. In addition, considering that Turkey's total gray water footprint is 17\% (Pegram et al. 2014), the gray water footprint value for Van province, which has limited industrial activities, is likely to be a very low amount. $\mathrm{WF}_{\text {domestic+industrial }}$ values obtained for Van province are similar to regions with low industrial capacity (Aldaya \& LIamas, 2008; Zeng et al., 2012; Muratoglu, 2019). Van Oel et al. (2009), in their study, stated that $\mathrm{WF}_{\text {domestictindustrial }}$ corresponded to $33 \%$ of the $\mathrm{WF}_{\text {total }}$. It was expected that the values for $\mathrm{WF}_{\text {domestictindustrial }}$ in regions with high industrial activities and dense population, would be high.

\subsection{Blue water scarcity}

Although $\mathrm{WS}_{\text {blue }}$ analysis can be applied on monthly and annual scales, its monthly determination provides a more detailed view as it will reveal seasonal variations 
(Muratoglu, 2019). However, since the main output of this study was the annual $\mathrm{WF}_{\text {blue }}$ average, $\mathrm{WS}_{\text {blue }}$ analysis was evaluated annually. Accordingly, the average annual WS $_{\text {blue }}$ of Van province between 2004 and 2019 was found to be $257 \%$, and it is a region with severe water scarcity in the classification stated by Hoekstra et al. (2012). This situation shows that $257 \%$ of blue water was used in Van province every year. If this situation continued, it is inevitable that it will experience serious water shortages in the near future.

It has been pointed out from $\mathrm{WS}_{\text {blue }}$ analysis of many basins that four billion people face water scarcity (Mekonnen and Hoekstra 2016). Mekonnen and Hoekstra (2011b) stated that in a study involving $\mathrm{WS}_{\text {blue }}$ analaysis on 223 basins, where 201 basins consumed more than twice the available blue water for at least one month a year. $\mathrm{WS}_{\text {blue }}$ exceeds $200 \%$ in the Euphrates-Tigris basin, which is located to the south and west of the Van province, especially in the summer when crops are produced (Degefu et al., 2018). In the Van, $\mathrm{WS}_{\text {blue }}$ was estimated to be higher in the summer months compared to locations like the Euphrates-Tigris basin, because the crop production season has inadequate precipitation and high temperatures (Figure 2). The $\mathrm{WS}_{\text {blue }}$ value for that part of the Tigris-Euphrates basin in Turkey was reported to have an annual average of $87 \%$ (Muratoglu, 2019). The reason for the $\mathrm{WS}_{\text {blue }}$ difference between the two province is due to the differences in the actual runoff, in the amount of $\mathrm{WF}_{\text {blue }}$ and in consumption habits and especially the climate. In addition, $\mathrm{WS}_{\text {blue }}$ can change according to the feeding conditions of the basins from different streams and the conditions of the region they serve.

\section{Conclusions}

In this study, the water footprints in Van province, which is located in the most easterly part of Turkey and is Turkey's fifth largest province in terms of surface area, were calculated. Crop production, livestock production and domestic-industrial water footprints have been analyzed over a wide time period (2004 to 2019) using current data, and the blue and green water footprints have been discussed in detail. The average water footprint of Van province was found to be 8.73 billion $\mathrm{m}^{3}$. Crop production is the main water-consuming sector in Van province being responsible for $87.6 \%$ of the total water footprint. More than half of the water footprint for crop production consists of blue water, i.e., underground and aboveground freshwater sources. Livestock production and domestic-industrial water footprints accounted for $4.9 \%$ and $7.5 \%$ of the total water footprint, respectively.

The crops that require intense water consumption are chickpeas, lentils, apples, beans (green), walnuts, grapes and apricots, respectively (Figure 6). These crops accounted for approximately $84 \%$ of the water footprint for crop production in Van. Therefore, the production of crops with low water consumption, such as onions, sugar beet, corn, potatoes, cabbage, watermelons, melons and eggplants, can be recommended for this province. When similar studies in literature were examined, it was seen that crop production generally consists of a green water footprint. However, it was concluded that the blue water footprints of crop products is higher than the green water footprints in Van province. Although this situation is caused by drought in the region, it may cause concerns in terms of the sustainability of the region's water resources in future years. Therefore, comparing the use of blue water with the economic value of the crops, and explaining the efficiency obtained from each unit of blue water, indicates the precautions to be taken in line with these results. In order to increase the efficiency of green water, changing the planting pattern of the crops or matching the planting-harvest dates of crops to the period that will benefit from precipitation is important for the protection of water resources. In arid and semi-arid regions, crop production using green water and the supply of other products from different regions may illustrate a different perspective on water footprint reduction. In addition, reducing evapotranspiration, rainwater harvesting and the use of modern irrigation methods can be considered as alternative approaches to reduce water footprint. In addition, biotechnological research is needed to develop crops that provide higher yields with less water consumption. In the Van, when feed crops are included in the water used by livestock, the water footprint of livestock production increased by $13.7 \%$ (Figure 9 ). This ratio revealed that feed crops have a high water consumption in this province. Therefore, it is important to use ready-made feed or use different regions to supply feed crops to help secure the future of water resources in arid and semi-arid regions. The study region, where migration is constantly experienced for a variety of reasons, exhibits a rapid population growth and low consumption, and the amount of freshwater per capita is rapidly decreasing-especially in the last four years (Figure 1)-while the domestic and industrial water footprints have increased over the years (Figure 10). For these reasons, the authorities need to take measures to reduce migration and the resulting population increase, and develop strategies to distribute the population evenly over its area.

The blue water scarcity value for Van province was found to be $257 \%$, which means $257 \%$ of available blue water is consumed every year. This value is an indication that Van province will experience a serious blue water crisis in the near future. For this, incentives should be provided for the consumption of food, goods and services with low water footprints, and steps should be taken in this direction by the authorities. The reduction of the water footprint for production in Van province is important for the sustainability of freshwater. Crops with high water footprints should be exported and detailed water footprint calculations should be renewed at certain periods. In addition, high resolution water footprint maps can be created for especially arid and semi-arid regions such as the Van province. Of course, data records should be established first for all these calculations. After these data are obtained, high temporal resolution studies on the blue water scarcity would provide better visibility of the sustainability of freshwater resources in the study region. Since there is a blue water crisis in the study region, reducing the use of blue water in the agricultural sector, carrying out studies on green water use and raising awareness of this is of great 
importance for the sustainability of water resources. It is recommended to cultivate products with high economic value requiring a low amount of blue water instead of products with low economic value and high blue water usage such as forage crops. For future research, the water footprint for consumption and virtual water transfer in the Van is suggested for investigation to reveal the water savings or deficits.

With this urban-scale study, it was concluded that the water footprint is a very useful approach to quantify water resources. Therefore, increasing studies to calculate water footprints on an urban scale will make a great contribution to developing policies and strategies. Finally, urban and basin-oriented water footprints based on production and consumption should be investigated by using up to date and realistic data instead of estimated data, and so comprehensive information can be obtained by carrying out studies in this area.

\section{References}

ADETORO, A.A., NGIDI, M., NYAM, Y.S. and ORIMOLOYE, I.R., 2021. Temporal evaluation of global trends in water footprint, water sustainability and water productivity research. Scientific American, vol. 12, pp. e00732. http://dx.doi.org/10.1016/j. sciaf.2021.e00732.

AERTS, J., MAJOR, D.C., BOWMAN, M.J., DIRCKE, P. and ARIS MARFAI, M., 2009. Connecting delta cities: coastal cities, flood risk management and adaptation to climate change. Amsterdam: VU University Press.

ALDAYA, M.M. and LIAMAS, M.R. 2008. Water footprint analysis for the Guadiana River basin. Netherlands: Unesco-IHE.

ALDAYA, M.M., MARTÍNEZ-SANTOS, P. and LLAMAS, M.R., 2010. Incorporating the water footprint and virtual water into policy: Reflections from the Mancha Occidental Region, Spain. Water Resources Management, vol. 24, no. 5, pp. 941-958. http://dx.doi. org/10.1007/s11269-009-9480-8.

ALLEN, R.G., PEREIRA, L.S., RAES, D. and SMITH, M. 1998. Crop evapotranspiration: guidelines for computing crop water requirements. Rome: FAO, 300 p.

AWANGE, J., 2021. Lake Victoria Monitored from Space. Champringe: Springer. Global Freshwater Resources

BOELENS, R. and VOS, J., 2012. The danger of naturalizing water policy concepts: water productivity and efficiency discourses from field irrigation to virtual water trade. Agricultural Water Management, vol. 108, pp. 16-26. http://dx.doi.org/10.1016/j. agwat.2011.06.013.

BORTOLINI, L., MAUCIERI, C. and BORIN, M., 2018. A tool for the evaluation of irrigation water quality in the arid and semi-arid regions. Agronomy (Basel), vol. 8, no. 2, pp. 23-53. http://dx.doi. org/10.3390/agronomy8020023.

BOSIRE, C.K., LANNERSTAD, M., DE LEEUW, J., KROL, M.S., OGUTU, J.O., OCHUNGO, P.A. and HOEKSTRA, A.Y., 2017. Urban consumption of meat and milk and its green and blue water footprint Patterns in the 1980s and 2000s for Nairobi, Kenya. The Science of the Total Environment, vol. 179, pp. 786-796. http://dx.doi.org/10.1016/j. scitotenv.2016.11.027. PMid:27847185.

BRINDHA, K., 2017. International virtual water flows from agricultural and livestock products of India. Journal of Cleaner Production, vol. 161, pp. 922-930. http://dx.doi.org/10.1016/j. jclepro.2017.06.005.
CAKMAK, B., KENDIRLI, B. and UCAR, Y., 2007. Evaluation of agricultural water use: A case study for Kizilirmak Basin. Tekirdag Ziraat Fakültesi Dergisi, vol. 4, no. 2, pp. 175-185.

CALZADILLA, A., REHDANZ, K. and TOL, R.S., 2011. Water scarcity and the impact of improved irrigation management: a computable general equilibrium analysis. Agricultural Economics, vol. 42, no. 3, pp. 305-323. http://dx.doi.org/10.1111/j.15740862.2010.00516.x.

CHAPAGAIN, A.K. and HOEKSTRA, A.Y., 2004. Water footprints of nations. Netherlands: Unesco-IHE.

CHAPAGAIN, A.K., HOEKSTRA, A.Y., SAVENIJE, H.H. and GAUTAM, R., 2006. The water footprint of cotton consumption: an assessment of the impact of worldwide consumption of cotton products on the water resources in the cotton producing countries. Ecological Economics, vol. 60, no. 1, pp. 186-203. http://dx.doi. org/10.1016/j.ecolecon.2005.11.027.

CHENG, X., CHEN, L., SUN, R. and JING, Y., 2019. Identification of regional water resource stress based on water quantity and quality: A case study in a rapid urbanization region of China. Journal of Cleaner Production, vol. 209, pp. 216-223. http:// dx.doi.org/10.1016/j.jclepro.2018.10.175.

CHICO, D., ALDAYA, M.M. and GARRIDO, A., 2013. A water footprint assessment of a pair of jeans: the influence of agricultural policies on the sustainability of consumer products. Journal of Cleaner Production, vol. 57, pp. 238-248. http://dx.doi. org/10.1016/j.jclepro.2013.06.001.

DAMANIA, R., 2020. The economics of water scarcity and variability. Oxford Review of Economic Policy, vol. 36, no. 1, pp. 24-44. http:// dx.doi.org/10.1093/oxrep/grz027.

DEGEFU, D.M., WEIJUN, H., ZAIYI, L., LIANG, Y., ZHENGWEI, H. and MIN, A., 2018. Mapping Monthly Water Scarcity in Global Transboundary Basins at Country-Basin Mesh Based Spatial Resolution. Scientific Reports, vol. 8, no. 1, pp. 2144. http:// dx.doi.org/10.1038/s41598-018-20032-w. PMid:29391421.

ERCIN, A.E. and HOEKSTRA, A.Y., 2014. Water footprint scenarios for 2050: A global analysis. Environment International, vol. 64, pp. 71-82. http://dx.doi.org/10.1016/j.envint.2013.11.019. PMid:24374780.

EWAID, S.H., ABED, S.A. and AL-ANSARI, N., 2019. Water footprint of wheat in Iraq. Water (Basel), vol. 11, no. 3, pp. 535. http:// dx.doi.org/10.3390/w11030535.

FADER, M., ROST, S., MULLER, C., BONDEAU, A. and GERTEN, D., 2010. Virtual water content of temperate cereals and maize: present and potential future patterns. Journal of Hydrology (Amsterdam), vol. 284, no. 3-4, pp. 218-231. http://dx.doi. org/10.1016/j.jhydrol.2009.12.011.

FOOD AND AGRICULTURA ORGANIZATION - FAO, 2018 [viewed 13 January 2020]. Crop Water Information [online]. Available from: http://www.fao.org/land-water/databases-andsoftware/ crop-information/en/

FU, Y., ZHAO, J., WANG, C., PENG, W., WANG, Q. and ZHANG, C., 2018. The virtual Water flow of crops between intraregional and interregional in mainland China. Agricultural Water Management, vol. 208, pp. 204-213. http://dx.doi.org/10.1016/j. agwat.2018.06.023.

GALAN-MARTIN, A., VASKAN, P., ANTON, A., ESTELLER, L.J. and GUILLÉN-GOSÁLBEZ, G., 2017. Multi-objective optimization of rainfed and irrigated agricultural areas considering production and environmental criteria: A case study of wheat production in Spain. Journal of Cleaner Production, vol. 140, pp. 816-830. http://dx.doi.org/10.1016/j.jclepro.2016.06.099.

GALLI, A., WIEDMANN, T., ERCIN, E., KNOBLAUCH, D., EWING, B. and GILJUM, S., 2012. Integrating ecological, carbon and water 
footprint into a "Footprint Family" of indicators: definition and role in tracking human pressure on the planet. Ecological Indicators, vol. 16, pp. 100-112. http://dx.doi.org/10.1016/j. ecolind.2011.06.017.

GE, L., XIE, G., ZHANG, C., LI, S., QI, Y., CAO, S. and HE, T., 2011. An evaluation of China's water footprint. Water Resources Management, vol. 25, no. 10, pp. 2633-2647. http://dx.doi. org/10.1007/s11269-011-9830-1.

GODAR, J., PERSSON, U.M., TIZADO, E.J. and MEYFROIDT, P., 2015. Towards more accurate and policy relevant footprint analyses: tracing fine-scale socio-environmental impacts of production to consumption. Ecological Economics, vol. 112, pp. 25-35. http:// dx.doi.org/10.1016/j.ecolecon.2015.02.003.

GUPTA, K.B., 2008. Water footprint of India and its implications for international trade in food products. South Asia Economic Journal, vol. 9, no. 2, pp. 419-433. http://dx.doi. org/10.1177/139156140800900208.

HOEKSTRA, A.Y. 2003. Virtual Water Trade: Proceedings of the International Expert Meeting on Virtual Water Trade. Netherlands: Unesco-IHE.

HOEKSTRA, A.Y., 2012. The hidden water resource use behind meat and dairy. Animal Frontiers, vol. 2, no. 2, pp. 3-8. http://dx.doi. org/10.2527/af.2012-0038.

HOEKSTRA, A.Y., 2014. Water scarcity challenges to business. Nature Climate Change, vol. 4, no. 5, pp. 318-325. http://dx.doi. org/10.1038/nclimate2214.

KLEMEŠ, J.J., 2015. Assessing and measuring environmental impact and sustainability. In: A.Y. HOEKSTRA. The water footprint of industry. Oxford: Butterworth-Heinemann, pp. 221-254.

HOEKSTRA, A.Y. and MEKONNEN, M.M., 2012. The water footprint of humanity. Proceedings of the National Academy of Sciences of the United States of America, vol. 109, no. 9, pp. 3232-3237. http://dx.doi.org/10.1073/pnas.1109936109. PMid:22331890.

HOEKSTRA, A.Y., CHAPAGAIN, A.K., ALDAYA, M.M. and MEKONNEN, M.M. 2011. The Water Footprint Assessment Manual. Water Footprint Network, Washington, London. 978-1-84971-279-8

HOEKSTRA, A.Y., MEKONNEN, M.M., CHAPAGAIN, A.K., MATHEWS, R.E. and RICHTER, B.D., 2012. Global monthly water scarcity: blue water footprints versus blue water availability. PLoS One, vol. 7, no. 2, pp. 1-9. http://dx.doi.org/10.1371/journal. pone.0032688. PMid:22393438.

IBIDHI, R., HOEKSTRA, A.Y., GERBENS-LEENES, P.W. and CHOUCHANE, H., 2017. Water, land and carbon footprints of sheep and chicken meat produced in Tunisia under different farming systems. Ecological Indicators, vol. 77, pp. 304-313. http://dx.doi.org/10.1016/j.ecolind.2017.02.022.

KANBER, R., 2010. Field Irrigation Systems. 2nd ed. Adana, Turkey: Cukurova University Faculty of Agriculture, General Publications.

KANBEROGLU, Z., 2016. A general assessment of the current situation of Van industry. Yuzuncu Yll University Faculty of Economics and Administrative Sciences Journal, vol. 1, pp. 25-38.

KARACA, S., SARGIN, B. and TURKMEN, F., 2019. Investigation of Some Land and Soil Properties by Geographical Information System Analysis: Van Province Land and Soil Properties. Turk Journal Agricultural Research, vol. 6, no. 2, pp. 199-205. http:// dx.doi.org/10.19159/tutad.542543.

KARCI, A.P. and UCAR, Y., 2019. Use of Remote Sensing and Geographic Information Systems in Irrigation Performance: A Case Study of Atabey Irrigation Scheme. Journal of The Institute of Natural \& Applied Sciences, vol. 6, no. 4, pp. 624-635. http:// dx.doi.org/10.30910/turkjans.633537.
LIU, J.G., YANG, H. and SAVENIJE, H.H.G., 2008. China's move to higher-meat diet hits water security. Nature, vol. 454, no. 7203, pp.397-397. http://dx.doi.org/10.1038/454397a. PMid:18650891.

LOVARELLI, D., BACENETTI, J. and FIALA, M., 2016. Water footprint of crop productions: a review. The Science of the Total Environment, vol. 548, pp. 236-251. http://dx.doi.org/10.1016/j. scitotenv.2016.01.022. PMid:26802352.

MALI, S.S., SINGH, D.K., SARANGI, A. and PARIHAR, S.S., 2018. Assessing water footprints and virtual water flows in Gomti River basin of India. Current Science, vol. 115, no. 4, pp. 721-728. http://dx.doi.org/10.18520/cs/v115/i4/721-728.

MANCOSU, N., SNYDER, R.L., KYRIAKAKIS, G. and SPANO, D., 2015. Water Scarcity and Future Challenges for Food Production. Water (Basel), vol. 7, no. 12, pp. 975-992. http://dx.doi.org/10.3390/ w7030975.

MEKONNEN, M.M. and HOEKSTRA, A.Y., 2010. The Green, Blue and Grey Water Footprint of Crops and Derived Products. Appendices. Netherlands: Unesco-IHE, vol. 2.

MEKONNEN, M.M. and HOEKSTRA, A.Y., 2011a. National water footprint accounts: The Green, Blue and Grey. Netherlands: Unesco-IHE. Value of Water Research Report Series.

MEKONNEN, M.M. and HOEKSTRA, A.Y. 2011b. Global Water Scarcity: The Monthly Blue Water Footprint Compared to Blue Water Availability for the World's Major River Basins. Unesco-IHE, Netherlands.

MEKONNEN, M.M. and HOEKSTRA, A.Y., 2011c. The green, blue and grey water footprint of crops and derived crop products. Hydrology and Earth System Sciences Discussions, vol. 15. http:// dx.doi.org/10.5194/hess-15-1577-2011.

MEKONNEN, M.M. and HOEKSTRA, A.Y., 2012. A global assessment of the water footprint of farm animal products. Ecosystems, vol. 15, no. 3, pp. 401-415. http://dx.doi.org/10.1007/s10021011-9517-8.

MEKONNEN, M.M. and HOEKSTRA, A.Y., 2014. Water footprint benchmarks for crop production: A first global assessment. Ecological Indicators, vol. 46, pp. 214-223. http://dx.doi. org/10.1016/j.ecolind.2014.06.013.

MEKONNEN, M.M. and HOEKSTRA, A.Y., 2016. Sustainability: four billion people facing severe water scarcity. Science Advances, vol. 2, no. 2, pp. e1500323. http://dx.doi.org/10.1126/sciadv.1500323. PMid:26933676.

MOHAMMADI-KANIGOLZAR, F., AMERI, J.D. and MOTEE, N., 2014. Virtual water trade as a strategy to water resource management in Iran. Journal of Water Resource and Protection, vol. 6, no. 02, pp. 141-148. http://dx.doi.org/10.4236/jwarp.2014.62019.

MORILLO, J.G., DIAZ, J.A.R., EMILIO, C.E. and PILAR, M.P., 2015. Linking water footprint accounting with irrigation management in high value crops. Journal of Cleaner Production, vol. 87, pp. 594-602. http://dx.doi.org/10.1016/j.jclepro.2014.09.043.

MURATOGLU, A., 2019. Water footprint assessment within a catchment: A case study for Upper Tigris River Basin. Ecological Indicators, vol. 106, pp. 105467. http://dx.doi.org/10.1016/j. ecolind.2019.105467.

MURATOGLU, A., 2020. Assessment of water footprint of production: A case study for Diyarbakır province. Journal of the Faculty of Engineering and Architecture of Gazi University, vol. 35, no. 2, pp. 845-858. http://dx.doi.org/10.17341/gazimmfd.543933.

NOVOA, V., AHUMADA-RUDOLPH, R., ROJAS, O., MUNIZAGA, J., SAEZ, K. and ARUMI, J.L., 2019. Sustainability assessment of the agricultural water footprint in the Cachapoal River basin, Chile. Ecological Indicators, vol. 98, pp. 19-28. http://dx.doi. org/10.1016/j.ecolind.2018.10.048. 
PATERSON, W., RUSHFORTH, R., RUDDELL, B.L., KONAR, M., AHAMS, I.C., GIRONAS, J. and MEJIA, A., 2015. Water footprint of cities: a review and suggestions for future. The International Journal of Life Cycle Assessment, vol. 7, pp. 8461-8490. http://dx.doi. org/10.3390/su7078461.

PEGRAM, G., CONYNGHAM, S., AKSOY, A., DIVRAK, B.B. and OZTOK, D. 2014 [viewed 19 November 2019]. Turkey's water footprint report: water, production and international trade relationship [online]. Turkey: WWF. http://awsassets.wwftr.panda.org/ downloads/su_ayak_izi_raporweb.pdf

SAHIN, U., KUSLU, Y., KIZILOGLU, F.M. and CAKMAKCI, T., 2016. Growth, yield, water use and crop quality responses of lettuce to different irrigation quantities in a semi-arid region high altitude. Journal of Applied Horticulture, vol. 18, no. 3, pp. 195202. http://dx.doi.org/10.37855/jah.2016.v18i03.34.

SENSOY, S., ERTEK, A., GEDIK, I. and KUCUKYUMUK, C., 2007. Irrigation frequency and amount affect yield and quality of field-grown melon (Cucumis melo L.). Agricultural Water Management, vol. 88, no. 1-3, pp. 269-274. http://dx.doi. org/10.1016/j.agwat.2006.10.015.

SIEBERT, S. and DOLL, P., 2010. Quantifying blue and green virtual water contents in global crop production as well as potential production losses without irrigation. Journal of Hydrology (Amsterdam), vol. 384, no. 3-4, pp. 198-217. http://dx.doi. org/10.1016/j.jhydrol.2009.07.031.

SONG, M., WANG, R. and ZENG, X., 2018. Water resources utilization efficiency and influence factors under environmental restrictions. Journal of Cleaner Production, vol. 184, pp. 611-621. http://dx.doi.org/10.1016/j.jclepro.2018.02.259.

SUN, S.K., WU, P.T., WANG, Y.B. and ZHAO, X.N., 2013. The virtual water content of major grain crops and virtual water flows between regions in China. Journal of the Science of Food and Agriculture, vol. 93, no. 6, pp. 1427-1437. http://dx.doi. org/10.1002/jsfa.5911. PMid:23174764.

TURKISH GENERAL DIRECTORATE OF AGRICULTURAL RESEARCH AND POLICIES - TAGEM, 2017 [6 January 2020]. Crop water consumption is to guide the Crops watered in Turkey. Ankara: Turkish General Directorate of Agricultural Research and Policies, Turkish General Directorate of State Hydraulic Works.

TURKISH STATISTICAL INSTITUTE - TSI, 2020. [viewed 5 January 2020]. [online]. Turkish Statistical Institute. Available from: http://www.turkstat.gov.tr/Start.do

TURKISH STATE METEOROLOGICAL SERVICE - TSMS, 2020. [viewed 2 January 2020]. [online]. Turkish State Meteorological Service. Available from: http://www.mgm.gov.tr
TUFENKCI, S., SONMEZ, F. and SENSOY, G.R., 2009. Determination of nutrient status of vineyards in Van Province. Harran University Journal of the Faculty of Agriculture, vol. 13, no. 4, pp. 13-22.

UNITED STATES DEPARTMENT OF AGRICULTURE - USDA, 1993. Part 623 National Engineering Handbook. Washington: USDA Soil Conservation Service Engineering Division. Chapter: 2 Irrigation Water Requirements.

VAN OEL, P.R., MEKONNEN, M.M. and HOEKSTRA, A.Y., 2009. The external water footprint of the Netherlands: geographicallyexplicit quantification and impact assessment. Ecological Economics, vol.69, no. 1, pp. 82-92. http://dx.doi.org/10.1016/j. ecolecon.2009.07.014.

VANHAM, D. and MEKONNEN, M.M., 2021. The scarcity-weighted water footprint provides unreliable water sustainability scoring. The Science of the Total Environment, vol. 756, pp. 143992. http:// dx.doi.org/10.1016/j.scitotenv.2020.143992. PMid:33302064.

VANHAM, D., HOEKSTRA, A.Y., WADA, Y., BOURAOUI, F., DE ROO, A., MEKONNEN, M.M., VAN DE BUND, W.F., BATELAAN, O., PAVELIC, P., BASTIAANSSEN, W.G.M., KUMMU, M., ROCKSTROM, J., BISSELINK, B., RONCO, P., PISTOCCHI, A. and BIDOGLIO, G., 2014. Physical water scarcity metrics for monitoring progress towards SDG target 6.4: An evaluation of indicator 6.4. 2 "Level of water stress". The Science of the Total Environment, vol. 613, pp. 218-232. PMid:28915458.

YERLI, C., SAHIN, U., CAKMAKCI, T. and TUFENKCI, S., 2019a. Effects of agricultural applications on $\mathrm{CO}_{2}$ emission and ways to reduce. Turkish Journal of Agriculture-Food Science and Technology, vol. 7, no. 9, pp. 1446-1456. http://dx.doi.org/10.24925/turjaf. v7i9.1446-1456.2750.

YERLI, C., SAHIN, U., KIZILOGLU, F.M., TUFENKCI, S. and SELDA, O., 2019b. Water Footprint of Silage Corn, Potato, Sugar Beet and Alfalfa in Van Province. Yuzuncu Yil University Journal of Agricultural Science, vol. 29, no. 2, pp. 195-203. http://dx.doi. org/10.29133/yyutbd.541890.

ZENG, Z., LIU, J., KOENEMAN, P.H., ZARATE, E. and HOEKSTRA, A.Y., 2012. Assessing water footprint at river basin level: A case study for the Heihe River Basin in northwest China. Hydrology and Earth System Sciences Discussions, vol. 16, no. 8, pp. 2771-2781. http://dx.doi.org/10.5194/hess-16-2771-2012.

ZHANG, C. and ANADON, L.D., 2014. A multi-regional input-output analysis of domestic virtual water trade and provincial water footprint in China. Ecological Economics, vol. 100, no. 5, pp. 159-172. http://dx.doi.org/10.1016/j.ecolecon.2014.02.006.

ZHUO, L., MEKONNEN, M.M. and HOEKSTRA, A.Y., 2014. Sensitivity and uncertainty in crop water footprint accounting: A case study for the Yellow River basin. Hydrology and Earth System Sciences Discussions, vol. 18, no. 6, pp. 2219-2234. http://dx.doi. org/10.5194/hess-18-2219-2014. 